\title{
Bilimin Doğası Hakkındaki Görüşlerin Kısa Hikâyeler Yöntemiyle Değerlendirilmesi: Fen Bilgisi Öğretmen Adayları Örneği ${ }^{*}$
}

\author{
Assessing Views About the Nature of Science by Vignettes: The Case of Prospective Science \\ Teachers
}

\section{Mahmut POLAT ${ }^{\dagger}$}

Özet

$\mathrm{Bu}$ araştırmanın amacı fen bilgisi öğretmen adaylarının bilimin doğası hakkındaki görüşlerini ölçek ve kısa hikâyeler yoluyla ayrı ayrı tespit etmek ve farklı yollardan tespit edilmiş olan bu görüşleri birbirleriyle karşılaştırarak kısa hikâyelerin ölçme değerlendirme aracı olarak öğretim ortamında etkililiğini belirlemektir. Araştırma çoklu durum çalışması içinde 79 Fen Bilgisi öğretmen adayı ile gerçekleştirilmiştir. Bilimsel Bilginin Doğası Ölçeği (BBDÖ) ve araştırmacı tarafından derlenen sekiz kısa hikâye $(\mathrm{KH})$ ile katılımcıların bilimin doğası hakkındaki görüşleri belirlenmiş kısa hikâyelerin bir ölçme değerlendirme yöntemi olarak nasıl kullanılabildiği ortaya konulmuştur. Çalışmaya ait veriler katılımcılardan 2011 yılının mayıs ayı içerisinde toplanmıştır. Analizler sonucunda katılımcıların farklı yollarla ölçülen bilimin doğası görüşlerinin birbirinden farklı oldukları görülmüştür. BBDÖ'den elde edilen puanlar $\mathrm{KH}^{\prime}$ lerden elde edilen puanlardan genelde daha yüksek çıkmıştır. Nitel verilerden elde edilen sonuçlara göre, katılımcıların bilimin doğasına yönelik bazı kavram yanılgılarına sahip oldukları görülmüştür. Çalışmadan elde edilen sonuçlar doğrultusunda alana katkı getirebileceği düşünülen bazı önerilere yer verilmiştir.

Anahtar kelimeler: Fen Eğitimi, bilimin doğası, ölçme- değerlendirme, kısa hikâyeler

\begin{abstract}
The present study aims to identify prospective science teachers' opinions on the nature of science via a scale and short stories and the effectiveness of short story as a measurement instrument by comparing those ideas gathered in different ways. The study was conducted among 79 prospective science teachers within a multiple-case study. Though the NSKS and the eight vignettes created by the researcher, the participants' views on the nature of science were identified and the use of vignettes as an assessment method was demonstrated. At the end of the analyses, it was determined that the participants' opinions on the nature of science, which was measured via different methods, varied from each other. The scores of NSKS were

\footnotetext{
* Bu makale; Prof. Dr. M. Fatih Taşar danışmanlığında Mahmut Polat tarafından hazırlanan “Bilimin doğası hakkındaki görüşlerin kısa hikâyeler yöntemiyle değerlendirilmesi: Fen bilgisi öğretmen adayları örneği" isimli doktora tezindeki verilerden elde edilmiştir.

† Dr. Öğr. Üyesi, Nevşehir Hacı Bektaş Veli Üniversitesi, Eğitim Fakültesi, Matematik ve Fen Bilimleri Eğitimi, mpolat@nevsehir.edu.tr
} 
generally higher than that of vignettes scores. According to the results obtained from qualitative data, participants have some misconceptions about the nature of science. Some suggestions have been made that may contribute to the field in the direction of the results obtained from the work.

Keywords: Science education, nature of science, measurement- assessment, vignettes

\section{Giriş}

İnsanların günlük yaşamlarındaki ve çalışma hayatlarındaki hızlı ve sürekli değişme, toplumu oluşturan bireyleri, hayat boyu öğrenme yeteneğini kazanmaya götürmektedir. Bu nedenle, eğitim sistemlerinin geleceğin çalışma hayatı uzmanlarını yetiştirmesi beklenmektedir. Bu bağlamda eğitim sistemleri sorgulanmakta ve sürekli bir değişim ve gelişim sürecine tabi tutulmaktalar (Atasoy, 2002). Hayat boyu öğrenme yeteneğine sahip özellikte bireylerin yetiştirilebilmesi için durgun-durağan eğitimöğretim programları değil, gelişen ve değişen programlara ihtiyaç duyulmaktadır. Şüphesiz bu durum eğitimin her alanında olduğu gibi Fen Bilgisi eğitimi alanında da yadsınamaz önemli bir gerçektir.

Geçmiş yıllardan günümüze gelinceye kadar fen eğitim ve öğretim programları incelendiğinde, tamamen aynı konular içermeseler de belli bazı ihtiyaçlar doğrultusunda bu programların zaman içerisinde benzer yönlerde değişimler geçirdikleri gözlemlenecektir. Bu değişimlerin en önemlilerinden biri de 1960 ve 1970'li yıllarda başlayan ve günümüzde de etkisini gösteren fen eğitiminin amaçlarına ilişkin reform hareketleridir. Bu reform hareketlerinde bilimsel okur-yazarlık veya fen ve teknoloji okur-yazarlı̆̆ı, artık fen eğitiminin en önemli hedeflerinden biri olarak gösterilmektedir (MEB, 2005; National Research Council [NRC], 1996; American Association for the Advencement of Science [AAAS], 1993; National Science Teacher Association [NSTA], 1982).

Fen eğitimi ve öğretimiyle ilgili ortaya çıkan yenilikçi çabalarının en önemli amacı bilimin doğasının öğrencilere öğretilmesi olmuştur. Bilimin doğası, öğrencilerin bilimsel okuryazar olabilmeleri açısından büyük önem taşımaktadır. Bu nedenle, bilimin doğası bilimsel okuryazarlığın en temel unsuru olarak kabul edilmektedir. Bilimin doğasının fen öğretim programları kapsamına alınması ve öğretilmesi gerektiği birçok eğitimci tarafından savunulmaktadır (Driver, Leach, Millar \& Scott, 1996; Hogan, 2000; Solomon, 1991).

Farklı uluslardan denekler üzerinde yapılan birçok araştırmada özellikle öğretmenlerin bilimsel okur-yazarlık ve onun bir boyutu olan bilimsel bilginin doğası hakkında modern bilim anlayışına uymayan yanlış anlayışlara sahip oldukları dile getirilmektedir (Abell \& Smith, 1994; Murcia \& Schibeci, 1999; Tsai, 2002). Bunun sonucu olarak, öğrencilerin de bilimsel bilginin doğası ve bilimsel okur-yazarlık hakkında geleneksel görüşlere sahip olduklarını ileri süren birçok araştırma yapılmıştır (Moss, Abrams, Robb, 2001; Haidar, 1999). Bu araştırmalarda da ileri sürüldüğü gibi, öğretmenlerin görüşlerinin öğrencilerin görüşlerini etkilediği 
söylenebilir. Bu nedenle öğretmenlerin bilimin doğasına ilişkin sahip oldukları görüşlerin belirlenmesi bilimin doğasıyla ilgili literatürde daha çok önem kazanmıştır.

Bilimin doğasına ilişkin özellikleri ölçmeye yönelik şimdiye kadar birçok yöntem denenmiştir. Bunlardan biri de kâğıt kalem kullanılarak öğrencilerin görüşlerinin tespit edilmeye çalışılan nitel yöntemlerdir. Lederman ve diğ. (2000) yaptığ1 çalışmada 1954- 1995 yılları arasında geliştirilen ve kullanılan 24 ölçek listelenerek kritik edilmiştir. Bu ölçeklerden 13 tanesinin geçerliliği üzerine odaklanan araştırmacılar bu ölçeklerin daha geçerli sayılabilen diğer ölçeklerle kullanılmasını önermişlerdir. Geriye kalan 11 ölçeğin ise geçerli ve güvenilir olduğu kabul edilmiştir. Taşar (2006).yapılan çalışmaların büyük bir kısmında kullanılan farklı ölçek ve teknikler örneklemdeki bireylerin konuya ilişkin kavram ve tutumlarını tam olarak detaylı ve özgür bir biçimde her hangi bir yönlendirmeye maruz bırakmaksızın açıklamalarına olanak sağlamaktan uzak olduğunu ileri sürmüştür.

Bilimin doğasıyla ilgili geliştirilen araçların, genellikle öğrencilerin ölçekte ki maddeleri aracı geliştiren kişilerle aynı şekilde anlayıp yorumladıkları gibi yanlış bir varsayıma dayandıkları belirtilmiştir. Hiçbir belirsizliğin olmadığı şeklindeki bu varsayım fen eğitimi araştırmacıları için geleneksel bir problem olmuştur (Lederman \& O'Malley, 1990; Aikenhead \& Ryan, 1992). Örneğin Lederman ve O'Malley (1990) bilimin geçiciliği konusunda öğrenci görüşlerinin araştırmacı ve öğrenciler tarafından kullanılan dilin farklılığına bağlı olarak değişkenlik gösterebildiğini belirtmişlerdir. Ayrıca Aikenhead' ın (1988) öğrenci ve öğretmenlerin bilimin doğası hakkındaki görüşlerini değerlendirmede uygun ölçme aracını seçmek için bir takım yardımcı bilgilere yer verdiği çalışmasında dört farklı cevaplama şeklindeki belirsizlik durumu dil problemi bakımından incelenmiştir. Öğrencilerin yazılı cevapları (likert tipi, paragraflar ve çok seçenekli) ve görüşmelerden elde edilen cevapları arasındaki uyumsuzluklar ölçülmüştür. Bu çalışmanın sonuçlarına göre likert tipi cevapların sadece öğrenci inançlarındaki bir tahmini ileri sürdüğünü ve doğru bir şekilde değerlendirme tahmininde bulunulma şansının çok düşük olduğu belirtilmiştir. Bu tür ölçeklerde belirsizliğin sık sık \% 80'ler seviyesine ulaştığı görülmüştür. Aynı çalışmada yarı-yapılandırılmış görüşmelerin tahminen en kolay anlaşılır olduğu ve doğru verileri sunduğu, belirsizliğin sadece yaklaşık \% 5 olduğu vurgulanmıştır.

Bireylerin sahip oldukları bilimin doğasına ilişkin görüşlerin ölçülmesinde ilgili literatür incelendiğinde çok büyük bir oranda ölçeklerin kullanıldığı görülmektedir. Oysaki bireysel farklılıklardan ötürü tek bir ölçme şekli bütün bireylere hitap etmeyebilir. Öğretim ortamlarında farklı (çoktan seçmeli, eşleştirmeli, essay vb.) ölçme değerlendirme yöntemlerinin kullanılması bireysel farklılıklar açısından daha adil bir ölçme ortamı sağlayacağı için bilimin doğasına yönelik görüşlerin belirlenmesinde de aynı yaklaşım sergilenerek alternatif ölçme değerlendirme yollarının geliştirilmesi bir ihtiyaç olarak karşımıza çıkmaktadır.

Yukarıda sıralanan nedenlerle daha önce öğretim amaçlı olarak kullanılan kısa hikâyeler bu çalışmada örneklemin bilimin doğasına ilişkin görüşlerini 
değerlendirmek için kullanılacaktır. Kullanılan bu teknikle katılımcıların bilimin doğasına ilişkin görülerini daha detaylı ve açık uçlu bir biçimde açılayabilmelerine imkân sağlanmıştır. Yapılan bu çalışmayla kısa hikâyelerin bu konuda bir ölçme değerlendirme aracı şeklinde alternatif bir yöntem olarak alana kazandırılması amaçlanmaktadır. Bu açıdan bu çalışma kısa hikâyeleri ölçme değerlendirme aracı olarak kullanılabilirliğini ortaya koyması bakımından alana önemli katkı getirebileceği düşünülmektedir.

\section{Çalışmanın amacı}

$\mathrm{Bu}$ çalışmanın amacı fen bilgisi öğretmen adaylarının bilimin doğası hakkındaki görüşlerini ölçek ve kısa hikâyeler yoluyla ayrı ayrı tespit etmek ve farklı yollardan tespit edilmiş olan bu görüşleri birbirleriyle karşılaştırarak kısa hikâyelerin ölçme değerlendirme aracı olarak öğretim ortamında etkililiğini belirlemektir.

\section{Çalışmanın kapsamı}

$\mathrm{Bu}$ çalışma, çalışmaya katılan yetmiş dokuz fen bilgisi öğretmen adayını kapsamaktadır. Ayrıca çalışmada kullanılmak üzere araştırmacı tarafından oluşturulan içerisinde bilimin doğasıyla ilgili özelliklerin ve kavramların bulunduğu kısa hikâyeleri kapsamaktadır. Araştırmacı tarafından kullanılan kısa hikâyelerde bilimin sadece gelişimsellik, test edilebilirlik, yaratıcılık boyutlarıyla ilgili verilere yer verilmiştir.

Çalışma esasen araştırmacının doktora tezinden derlendiği için veri toplama aracı olan kısa hikâyelerin ve rubriklerin geliştirilmesi, güvenirlik-geçerlik çalışmaları bu çalışmanın kapsamı dışında bırakılmıştır.

\section{Çalışmanın Yöntemi}

\section{Çalışma modeli}

Fen bilgisi öğretmen adaylarının bilimin doğası hakkındaki görüşlerinin kısa hikâyelerle belirlenmesi amacıyla yapılan bu araştırmada, katılımcıların bilimin doğasına yönelik görüşleri ölçek ve kısa hikâyeler aracılığıyla tespit edilerek karşılaştırılacaktır. Bu durum hakkında derinliğine ve genişliğine bilgi toplamak için nitel araştırmalardan "çoklu durum çalışması" araştırma yönteminden yararlanılmıştır.

\section{Katılımcilar}

$\mathrm{Bu}$ çalışmada bir evren ve örneklem grubu belirlenmemiştir çünkü durum çalışmalarında araştırmanın amacı, bir evrene istatistiksel genellemeler yapmak yerine analitik genellemeler yapmaktır. Yani, kuram oluşturmak veya kuramsal önermelerde 
bulunmaktır. Bu sebeple durum çalışmalarında temsili bir örneklemden söz edilmez (Yıldırım ve Şimşek, 2006).

Bu çalışmada Ankara'da ki büyük bir üniversitenin fen bilgisi öğretmenliği üçüncü sınıfında okuyan 79 kişilik bir öğretmen adayı gurubu seçilmiştir. Bu katılımcıların 68'i kız, 11'i erkek öğretmen adaylarından oluşmuştur. 2010 yılının mayıs ayında fen bilgisi öğretmen adaylarına, bilimin doğası ve bilim tarihi dersinde on hafta ilgili öğretim elemanı dersi tamamladıktan sonra, araştırmacı tarafından oluşturulan güvenirliği ve geçerliği sağlanan (Polat, 2011) kısa hikâyeler uygulanmıştır. Daha sonra diğer veri toplama aracı olan bilimsel bilginin doğası ölçeği (BBDÖ) uygulanmıştır.

\section{Veri toplama araçları}

Bilimsel bilginin doğası ölçeği (Nature of Scientific Knowledge Scala) Rubba tarafından 1978 yılında geliştirilmiştir. Ölçek her birinde 8 madde olan altı boyuttan oluşmaktadır. Bu boyutlar test edilebilirlik, gelişimsellik, sadelik, ahlak dişılık, bütünsellik, yaratıcılık olarak sıralanabilir. Ölçek, beş seçenekli (Tamamen Katılıyorum, Katılıyorum, Kararsızım, Katılmıyorum, Hiç Katılmıyorum) likert tipinde 48 önermeden oluşmaktadır. Ölçeğin gelişiminde kullanılan bilimsel bilgi modeli hem basit hem de genel anlamda bilimin doğasıyla ilgili bütün unsurları içermektedir.

Bilimsel Bilginin Doğası Ölçeğinin (BBDÖ) Türkçe' ye adaptasyonu Bilgiç (1985) tarafından yapılmıştır. Ölçeğin güvenirliği Split-Half yöntemiyle hesaplanarak 0,79 bulunmuştur. Bu çalışma için toplanan verilerin araştırmacı tarafından yapılan güvenirlik analizi sonucu BBDÖ güvenirliği yine split-half yöntemiyle hesaplanarak 0,82 olarak bulunmuştur.

$\mathrm{Bu}$ çalışmada kullanılan bir diğer veri toplama aracı kısa hikâyelerdir (KH). Kısa hikâyeler şimdiye kadar eğitimin farklı alanlarında farklı formlarda bilgi toplamak için kullanılmıştır. Kısa hikâyeler nitel olma özelliklerinden ötürü, daha derinlemesine bilgi sağlamaları ve küçük bir örnekleme uygulanabilmesi gibi belli avantajlara sahiptir (Taşar, 2006). Bu çalışmada kullanılan kısa hikâyeler Türkiye'de yayınlanmakta olan popüler dergilerden, kitaplardan ve gazete yazılarından derlenmiştir. Bu kısa hikâyeleri çerisinde bilimin doğasına ilişkin unsurlar ve özellikler çokta açık ve belli olmayan bir şekilde yer almaktadır. Her bir kısa hikâyede bilimin doğasına ilişkin tek bir özellik yer alabilirken birden fazla özellikte yer alabilmektedir.

Bir öykü akışı içerisinde olan kısa hikâyelerin bilim tarihi içerisinde önemli yer tutan paradigma dönüşümlerine öncülük eden bilim insanlarının yaşamlarından kesitler de içerebilmektedir. Kısa hikâyelerin içerisinde olan bilimin doğasına yönelik özelliklerin sorularla katılımcılar tarafından okunarak bulunması ve buna ilişkin görüşlerini yazması istenilmektedir. 


\section{Verilerin analizi}

Ölçek 48 önermeden oluşan altı alt boyutu olan bir yapıya sahip olduğu için katılımcıların ölçeğe verdiği cevaplarda her bir önermenin likert değeri yazılmıştır. Böylece her bir alt boyuta ait frekans, yüzde, ortalama gibi betimsel analizler yapılmıştır. Ayrıca ölçeğin tamamına ait puanlar da hesaplanmıştır. Ancak çalışma sadece bilimin gelişimsellik, test edilebilirlik ve yaratıcılık boyutlarını kapsadığı için ölçeğin sayılan üç boyutuna ait veriler kullanılmıştır. Bunun yanı sıra ölçeğin alt boyutlarında yer alan önermelere verilen cevaplara ilişkin betimleyici analizlere de yer verilerek öğretmen adaylarının bu önermelerde yapmış oldukları seçimlerle bilimin doğası hakkındaki anlayışları belirlenmeye çalışılmıştır.

Kısa hikâyelere verilen cevapların değerlendirilmesinde rubrikler kullanıldığı için katılımcıların kısa hikaye yönteminden (KHY) aldıkları puanlar (rubrikten elde edilen puanlar) gerektiğinde ölçekteki alt boyutlarla ve bunlar içinde yer alan ilgili önermelerle karşılaştırılabilme imkânı sağlamıştır. Kısa hikâyelerde yer alan açık uçlu sorulara verilen yazılı cevapların analizinde ise içerik analizi yöntemi kullanılmıştır.

\section{Bulgular ve Yorum}

\section{BBDÖ' den elde edilen bulgular}

Bu çalışmada kullanılan BBDÖ’ den elde edilen bulgular tablo I' de sunulmuştur.

Tablo 1. Katılımcıların Bilimsel Bilginin Doğası Ölçeğine ait bulgular

\begin{tabular}{lccccc}
\hline B. Doğası Boyutu & $N$ & $\bar{X}$ & $S D$ & Min. & Max. \\
\hline Gelişimsellik & 79 & 30,03 & 3,35 & 23 & 38 \\
Test edilebilirlik & 79 & 32,42 & 3,04 & 25 & 39 \\
Yaratıcılık & 79 & 27,10 & 5,90 & 13 & 38 \\
Toplam & 79 & 89,54 & 8,26 & 76 & 111 \\
\hline
\end{tabular}

Tablo 1'e göre bilimin doğası boyutlarından gelişimsellik, test edilebilirlik, yaratıclık boyutlarından alınan puanların ortalamaları görece birbirine yakındır. En yüksek ortalamaya sahip olan test edilebilirlik $(\bar{X}: 32,42)$ boyutunu gelişimsellik $(\bar{X}$ : $30,03)$ boyutu takip etmektedir. Diğerlerine göre daha düşük bir değere sahip olan yaratıc1lı boyutunun ortalaması $27,10^{\prime}$ dur. Boyutlara ait en yüksek puan 39 puan ile test edilebilirliğe ait iken en düşük değer 13 puan ile yaratıcılık alt boyutundan alınmıştır. Ölçeğin her bir boyutundan alınabilecek en küçük ve en büyük puanın sırasıyla 8 ve 40 olduğu göz önüne alındığında öğretmen adaylarının puanlarının yüksek olduğu söylenebilir. 
Ölçeğin gelişimsellik alt boyutundaki önermelere ait bulgular tablo 2'de sunulmuştur.

Tablo 2. Gelişimsellik Alt Boyutundaki Önermelere Ait Bulgular

\begin{tabular}{llllllllllll}
\hline $\begin{array}{l}\text { Ö. } \\
\text { No }\end{array}$ & & & $\mathbf{1}$ & & $\mathbf{2}$ & & $\mathbf{3}$ & & $\mathbf{4}$ & & $\mathbf{5}$ \\
\cline { 2 - 11 } & & $\mathrm{f}$ & $\%$ & $\mathrm{f}$ & $\%$ & $\mathrm{f}$ & $\%$ & $\mathrm{f}$ & $\%$ & $\mathrm{f}$ & $\%$ \\
\hline 16 & 2,59 & 12 & 15,2 & 32 & 40,5 & 12 & 15,2 & 22 & 27,8 & 1 & 1,3 \\
26 & 4,16 & 1 & 1,3 & - & - & 2 & 2,5 & 58 & 73,4 & 18 & 22,8 \\
37 & 4,15 & 1 & 1,3 & 3 & 3,8 & 2 & 2,5 & 50 & 63,3 & 23 & 29,1 \\
42 & 3,82 & - & - & 5 & 6,3 & 14 & 17,7 & 50 & 63,3 & 10 & 12,7 \\
25 & 3,73 & 4 & 5,1 & 5 & 6,3 & 10 & 12,7 & 49 & 62 & 11 & 13,9 \\
27 & 3,43 & 9 & 11,4 & 5 & 6,3 & 15 & 19 & 43 & 54,4 & 7 & 8,9 \\
31 & 3,97 & 2 & 2,5 & - & - & 10 & 12,7 & 53 & 67,1 & 14 & 17,7 \\
43 & 4,15 & 3 & 3,8 & - & - & 6 & 7,6 & 43 & 54,4 & 27 & 34,2 \\
\hline
\end{tabular}

Tablo 2'deki bulgulardan katılımcıların bilimi gelişime ve değişime açık bir etkinlik olarak gördükleri, bilimsel bilgileri de sorgulanabilir bilgiler olarak kabul ettikleri ve bilimsel bilgileri bütün hatalardan azade olarak algıladıkları söylenebilir. Ancak burada dikkat edilmesi gereken bir noktayı gözden kaçırmamak gerekir. Her ne kadar katılımcıların birçoğu bilimin gelişime ve değişime açık olduğunu söylese ve bilimsel bilgilere de şüpheyle yaklaşmak gerektiğini belirtmiş olsa da bilimsel bilgileri bütün hatalardan arındırılmış bilgiler olarak görmeleri (16. ve 27. önerme) bir çelişki olarak kabul edilmelidir. Çünkü madem bilim gelişimseldir ve bilgiler her dönemde sorgulanabilir o zaman bu bilgilerin mutlak anlamda kesin ve doğru bilgiler olduğu söylenebilir mi? Burada ortaya çımış olan bu çelişkinin olası nedenlerini belirlemeye eldeki ölçeğin yeterli gelemeyeceği açıktır. Bu nedenle katılımcıların bilimin doğası hakkındaki görüşlerini belirlemede farklı yöntemlere başvurulması gerekir. Ölçeğin test edilebilirlik alt boyutundaki önermelere ait bulgular tablo 3'te sunulmuştur.

Tablo 2. Test Edilebilirlik Alt Boyutundaki Önermelere Ait Bulgular

\begin{tabular}{lrllllllllll}
\hline Ö. & & & $\mathbf{1}$ & & $\mathbf{2}$ & & $\mathbf{3}$ & & $\mathbf{4}$ & & $\mathbf{5}$ \\
\cline { 2 - 11 } No & $\bar{X}$ & $\mathrm{f}$ & $\%$ & $\mathrm{f}$ & $\%$ & $\mathrm{f}$ & $\%$ & $\mathrm{f}$ & $\%$ & $\mathrm{f}$ & $\%$ \\
\hline 12 & 3,70 & - & - & 5 & 6,3 & 16 & 20,3 & 56 & 70,9 & 2 & 2,5 \\
22 & 4,18 & 1 & 1,3 & 1 & 1,3 & 5 & 6,3 & 48 & 60,8 & 24 & 30,4 \\
38 & 4,10 & - & - & 3 & 3,8 & 2 & 2,5 & 58 & 73,4 & 16 & 20,3 \\
45 & 4,14 & 2 & 2,5 & - & - & 4 & 5,1 & 52 & 65,8 & 21 & 26,6 \\
9 & 4,09 & 3 & 3,38 & - & - & 7 & 8,9 & 46 & 58,2 & 23 & 29,1 \\
11 & 4,27 & 2 & 2,5 & - & - & 2 & 2,5 & 46 & 58,2 & 29 & 36,7 \\
13 & 3,84 & 6 & 7,6 & - & - & 10 & 12,7 & 48 & 60,8 & 15 & 19 \\
33 & 4,11 & 2 & 2,5 & - & - & 6 & 7,6 & 50 & 63,3 & 21 & 26,6 \\
\hline
\end{tabular}

Tablo 3'e göre bilimin test edilebilirlik boyutuna ait önermelere katılımciların genelde katıldıkları anlaşılmaktadır. Önermelere ait ortalama puanlar 3,70 ile 4,27 arasında değişmektedir. Hem olumlu hem de olumsuz ifadelerde öğrencilerin almış oldukları puanların yüksek olduğu söylenebilir. Sadece on ikinci ve on üçüncü 
önermelere ait ortalama puanların diğerlerine göre bir miktar düşük olduğu görülse de katılımcıların \% 70'den fazlasının bu noktada aynı düşündüğü söylenebilir. Yani bilimsel bilgilerin toplum denetimine açık olması gerektiği noktasında çoğunlukla hem fikir oldukları söylenebilir. Ancak burada özellikle on ikinci önerme de katılımcıların beşte birinin kararsız kalmış oldukları da göz önünde bulundurulmalıdır. Kararsız kalan bu katılımcıların bilimsel bilginin toplum incelemesine açık olması gerektiği noktasında neden kararsız kaldıkları ortaya çıkarılmalıdır. Çünkü bu kararsız olan katılımcıların bir kısmı diğer önermelerde bilimsel bilginin tekrarlanabilir ve sonuçlarının tutarlı olması gerektiğine olumlu görüş bildirmişlerdir.

Tablo 3'teki bulgulardan bilimin doğasının test edilebilirlik boyutuyla ilgili olarak katılımcıların genelinin bilimin gözlem ve deneylere dayanması gerekliliğini, deney sonuçlarının tutarlılığını ve tekrarlana bilirliğini kabul ettikleri söylenebilir.

Ölçeğin yaratıcılık alt boyutundaki önermelere ait bulgular tablo 4'te sunulmuştur.

Tablo 4. Yaratıcllk Alt Boyutundaki Önermelere Ait Bulgular

\begin{tabular}{llllllllllll}
\hline Ö. & & & $\mathbf{1}$ & & $\mathbf{2}$ & & $\mathbf{3}$ & & $\mathbf{4}$ & & $\mathbf{5}$ \\
\cline { 2 - 12 } No & $\bar{X}$ & $\mathrm{f}$ & $\%$ & $\mathrm{f}$ & $\%$ & $\mathrm{f}$ & $\%$ & $\mathrm{f}$ & $\%$ & $\mathrm{f}$ & $\%$ \\
\hline 17 & 3,85 & - & - & 11 & 13,9 & 7 & 8,9 & 44 & 55,7 & 17 & 21,5 \\
20 & 3,76 & - & - & 9 & 11,4 & 11 & 13,9 & 49 & 62 & 10 & 12,7 \\
28 & 3,53 & 5 & 6,3 & 7 & 8,9 & 18 & 22,8 & 39 & 49,4 & 10 & 12,7 \\
32 & 3,38 & 2 & 2,5 & 16 & 20,3 & 21 & 26,6 & 30 & 38 & 10 & 12,7 \\
1 & 3,82 & 4 & 5,1 & 5 & 6,3 & 9 & 11,4 & 44 & 55,7 & 17 & 21,5 \\
23 & 3,20 & 22 & 27,8 & - & - & 11 & 13,9 & 32 & 40,5 & 14 & 17,7 \\
34 & 3,86 & 8 & 10,1 & - & - & 5 & 6,3 & 48 & 60,8 & 18 & 22,8 \\
41 & 1,76 & 53 & 67,1 & - & - & 18 & 22,8 & 8 & 10,1 & - & - \\
\hline
\end{tabular}

Tablo 4'e göre bilimin yaratıcılık boyutuna ait önermelere kırk birinci önerme dışında genelde katıldıkları söylenebilir. Bu önerme dışında kalan diğer önermelere ait ortalama puanlar 3,20 ile 3,86 arasında değişmektedir. Daha önce verilmiş olan gelişimsellik ve test edilebilirlik boyutuna ait ölçek puanlarıyla karşılaştırıldı ̆̆ında katılımcıların yaratıcılık boyutundan daha düşük puanlar aldıkları görülecektir. Ayrıca kırk birinci önermeyle ilgili olarak katılımcıların yarısından fazlasının (\% 67,1) bilimsel bilgilerin keşfedildiği icat edilmedikleri inancına sahip oldukları şeklinde ifade edilebilir. Bu sonuç diğer önermelerden elde edilen bulgularla birlikte düşünüldüğünde ortada bir sorun olduğu söylenebilir. Katılımcılar diğer önermelerde bilimin yaratıcı doğasına ilişkin önermelere büyük çoğunlukla katılırken son önermeye katılmamışlardır. Oysaki son önermede geçen icat etme kavramı bilimsel bilginin ve bilim insanlarının yaratıcı yönüne vurgu yapan bir ifadedir. Bunun olası bir nedeni katılımcıların icat ve keşif terimlerini tam olarak algılayamamış olmaları olabilir. Katılımcıların bu önermeye verdikleri cevapların nedeni daha detaylı bir şekilde farklı değerlendirme yöntemleriyle ortaya konulmalıdır. 


\section{KHY den Elde Edilen Bulgular}

$\mathrm{Bu}$ çalışmada kullanılan $\mathrm{KHY}^{\prime}$ den elde edilen bulgular aşağıdaki tabloda sunulmuştur. Öncelikle kısa hikâyelerdeki sorulara verilen cevapların değerlendirildiği rubrik puanlarından elde edilen genel sonuçlar sıralanmıştır. Daha sonra ise sorulan sorulara verilen cevaplardan elde edilen nitel bulgularla tablo V deki bulgular destelenecektir.

Tablo 5. Katılımcıların Bütün K. Hikâyelerden Aldıkları Rubrik Puanlarına Ait Bulgular

\begin{tabular}{lccccccc}
\hline $\begin{array}{l}\text { B.Doğası } \\
\text { Boyutu }\end{array}$ & $\mathrm{N}$ & $\bar{X}$ & $\mathrm{SD}$ & $\begin{array}{l}\text { Min. } \\
\text { Puan }\end{array}$ & $\begin{array}{l}\text { Max. } \\
\text { Puan }\end{array}$ & $\begin{array}{l}\text { KHY } \\
\text { Min. } \\
\text { Puan }\end{array}$ & $\begin{array}{l}\text { KHY } \\
\text { Max. Puan }\end{array}$ \\
\hline Gelişimsellik & 79 & 12,29 & 5,33 & 5 & 27 & 0 & 35 \\
Test Edilebilirlik & 79 & 13,46 & 5,12 & 5 & 29 & 0 & 35 \\
Yaratıcılik & 79 & 6,64 & 3,32 & 3 & 15 & 0 & 15 \\
Toplam & 79 & 32,40 & 11,05 & 14 & 69 & 0 & 85 \\
\hline
\end{tabular}

Tablo 5' e göre katılımcılar, kısa hikâyelerden rubrik aracılığıyla en yüksek puanları $(\bar{X}: 13,46)$ test edilebilirlik boyutundan almaktadırlar. En düşük puanların ise 6,64 ortalamayla yaratıcllık boyutundan geldiği görülmektedir. Kisa hikâyelerin tamamından alınan toplam rubrik puanlarına bakıldığında ortalamanın 32,40 olduğu, alınan en yüksek puanın ise 69 olduğu görülmektedir. Bu tablodaki verilerin okuyucuya daha anlamlı gelebilmesi için katılımcıların KHY de bilimin doğasıyla ilgili her birinin alabilecekleri maksimum (85) ve minimum (0) puanları göz ardı etmemeleri gerekir.

Katılımcıların ölçeğin tamamından almış oldukları puanlarla (Tablo 1) rubriklerden almış oldukları puanlar (Tablo 5) bir arada değerlendirildiğinde birbirine paralel bazı sonuçlar görülebilir. Hem ölçekten hem de rubriklerden elde edilen en yüksek puan ortalamaları test edilebilirlik boyutuna aittir. Daha sonra sirasıyla gelişimsellik ve yaratıcılık boyutlarına ait puanlar sıralanabilir. Ancak öğretmen adayları BBDÖ sonuçlarına göre yüksek sayılabilecek puanlar alırken kısa hikâyelerden elde edilen rubrik puanlarına göre çok düşük ortalamalara sahip olmuşlardır (tablo 5). Ayrıca her ne kadar en düşük ortalamalar her iki ölçme yöntemine göre yaratıcılık boyutundan gelmiş olsa da KHY ile elde edilen yaratıcılık puan ortalamasının $(\bar{X}: 6,64) 15$ tam puan üzerinden alındığ 1 unutulmamalıdır. Yani aslında katılımcılar KHY ile yaratıcılıktan almış oldukları rubrik puanları diğer iki boyuta göre daha yüksek olduğu söylenebilir. Bu durum aşağıda sıralanan nitel bulgulardan da açıkça gözlemlenebilir.

Üçüncü kısa hikâyenin ikinci ve üçüncü soruları öğretmen adaylarının bilimin gelişimsellikle ilgili görüşlerini ortaya çıkarmak için hazırlanmıştır. Bu sorulara verilen cevaplar birlikte değerlendirilerek analiz edilmişlerdir. Aşağıda iki numaralı soruya verilen cevaplardan yapılan alıntılar sunulmuştur; 


\begin{abstract}
“Soru 2: Hem Batlamyus' un modeli hem de Kopernik' in modeli evrenin yapısını açıklamak için öne sürülmüş farklı görüşlerden oluşmuş modellerdir. Parçaya göre bu modellerden hangisi zaman içerinde tercih edilmiştir? Sizce nedeni ne olabilir? (Kısa hikâye 3, soru 2)
\end{abstract}

K-26: Her bilimsel açıklama o zamanın şartlarıla değerlendirilmelidir. Yani ileri teknolojili teleskoplar icat edilene kadar Batlamyus' un modeli açıklayıcı ve kabul edilebilirdi. Ama Kopernik bulunduğu zamana göre çok aykır bir görüş ortaya sürmüş gibi görünüyordu. Bu nedenle doğruluğunun kabul edilmesi zaman aldr. (Kısa hikâye 3, soru 2, A31)

K-36: Kopernik' in modeli tercih edildi. Bilim insanlar yeni keş̧edilmiş teleskopların gökyüzüne çevirip Kopernik' in ileri sürdü̆̆̈̈ düşüncenin doğru olduğunu kanıtladılar. (Kısa hikâye 3, soru 2, A33)

K-49: Illk zamanlarda Batlamyus'un düşüncesi kabul edilmiştir. Bilgiler zamana göre farklhlı gösterebilir yani kabul görmesi değişebilir. O zamanlar insanlar dünyanın tüm evrenin merkezinde ve görkemli bir gezegen olduğunu düşünüyorlardı kimse gerçeklerle değil de bu büyüleyici düşünceyle ilgileniyorlardı. Bu nedenle Batlamyus'un fikirleri kabul gördü ve yeni fikirler ortaya çıktı̆̆ında insanlar rahatsız oldu. Insanlar doğru veya yanhış bilgiyi umursamıyorlardı bu fikir onların hoşuna gidiyordu. Ancak daha sonra Kopernik'in yaptı̆̆ çalışmalar başta büyük tepki uyandırsa da sonraları gerçek bilgi olduğu için insanlar tarafindan kabul görmüş ve benimsenmiştir. (Kısa hikâye 3, soru 2, A34)"

$\mathrm{Bu}$ araştırmada bilimin gelişimsellik boyutuyla ilgili sorulara öğretmen adaylarının vermiş oldukları cevaplardan elde edilen bulgulara bakıldığında genel olarak şu sonuçlar sıralanabilir. Öğretmen adaylarının bilimsel bilgi türlerinin (hipotez, yasa, teori) tanımlanmasında ve aralarındaki ilişkilerin ortaya konulmasında yetersiz oldukları, katılımcıların çoğunun bilimin birikimli bir şekilde geliştiğine, az bir kısmının ise bilimsel devrimlerle de gelişebileceğine inandıkları, bilimsel bilgilerin değişiminin oldukça zor ve zaman isteyen bir süreç olarak kabul ettikleri görülmüştür. Bunun yanı sıra öğretmen adaylarının gelişimsellik boyutunu test edilebilirlik boyutuyla birlikte düşündükleri ve kanıtlanabilirliğin (olgusal temellere dayanmanın) bilimsel bilgilerin değişiminde ve tercih edilmesinde esas rolü oynadığını kabul ettikleri görülmüştür.

BBDÖ’ nin gelişimsellikle ilgili verilerine bakıldığında (Tablo II) her ne kadar katılımcıların birçoğu bilimin gelişime ve değişime açık olduğunu söylese ve bilimsel bilgilere de şüpheyle yaklaşmak gerektiğini belirtmiş olsa da bilimsel bilgileri bütün hatalardan arındırılmış bilgiler olarak görmeleri (16. ve 27. önerme) bir çelişki olarak kabul edilmelidir. Çünkü madem bilim gelişimseldir ve bilgiler her dönemde sorgulanabilir o zaman bu bilgilerin mutlak anlamda kesin ve doğru bilgiler olduğu söylenebilir mi? Ortaya çıkan bu çelişkinin aslında ölçekten (BBDÖ) kaynaklanan toptancı anlayışın bir yansıması olarak görmek mümkündür. Çünkü kısa hikâyelerden elde edilen nitel bulgular incelendiğinde üçüncü kısa hikâyenin 2 . sorusuna cevap veren adayların bir bölümünün (Örnek: K-26) bilimsel bilgileri de bulundukları zamanın şartlarına bağlı olarak değerlendirmenin doğru olacağına inandıkları görülmüştür. Bir başka deyişle öğretmen adaylarının az da olsa bir bölümü bilimsel bilgi olarak kabul edilen açıklamaların da içerisinde yanlış barındırabileceği ve bilimde bunun için sorgulamanın ve şüpheciliğin önemli olduğuna inandıkları görülmüştür. 
İkinci kısa hikâyenin 2. sorusu ve üçüncü kısa hikâyenin 4. sorusu genel olarak bilimin test edilebilirlik boyutuyla ilgili görüşlerini ortaya çıkarmak için sorulmuştur. $\mathrm{Bu}$ sorulara verilen cevaplar birlikte değerlendirilerek analiz edilmişlerdir. Aşağıda dört numaralı soruya verilen cevaplardan yapılan alıntılar sunulmuştur.

"Soru 4: Bir olayı ya da olguyu açıklamaya çalışan iki alternatifgörüş ya da model varsa hangisi tercih edilmelidir? Yukarıdaki parçadan da örnekler vererek nedenleriyle açıklayınız. (Kısa hikâye 3, soru 4)

K-26: Şartları en iyi açıklayan, tek bir durum için değil gözlenebilecek her durum için desteklenebilen görüş kabul edilmelidir. Yani objektif olarak bulunduğumuz ortamın siyasi ve dini görüşlerinden arınarak akla daha yatkın olan kabul edilmelidir. Örneğin parçanın 3. Paragrafinda Kopernik'in modelinin kabul görmemesinin nedeni tamamıyla insanların dar görüşlü olmalarındandır. Oysaki bütün gözlemler onu doğruluyordu ve bilim olgusaldır. (Kisa hikâye 3, soru 4, A70)

K-30: Daha sade yalın anlaşılır olan tercih edilmelidir. "...Yildıları incelerken Kopernik'in aklina bir fikir geldi. Batlamyus modeline giderek daha karmaşık ilaveler yapmak yerine tek bir değişiklik yapılırsa model çok daha basit olacaktı..." cümlesi buna örnek olabilir. (Kisa hikâye 3, soru 4, A71)

K-36: Tabi ki gözlemlerle ve deneylerle ortaya konulan açılamalar zamanla tercih edilir. Bilimi diğer bilgilerden ayıran temel özellik olgu dünyasında ve test edilebilir olması. (Kısa hikâye 3, soru 4, A72)"

Bilimin test edilebilirlik boyutuyla ilgili soruların cevaplarından elde edilen bulgular birlikte değerlendirildiğinde öğretmen adaylarının birçoğunun bilimsel bilgilerin tercih edilmesinde ve toplumda geçerlilik kazanmasında olgusal gözlemlere ve deneylere dayandırılması gerektiğine inanmakta oldukları görülmüştür. Ayrıca bazı öğretmen adaylarının farklı bir bakış açısı sergileyerek bilimsel araştırmalarda ilk önce gözlemlerin yapıldığı daha sonra kuramsal yapıların oluşturulduğu belirtilmiştir. Aslında çağdaş bir bilim anlayışında bilim insanlarının sahip olduğu kuramsal yapılar onların gözlemlerini de belirleme de son derece önemlidir. Bazı öğretmen adayları ise mutlak anlamda bir kantlanabilirliğin olamayacağını ve gözlemlerin teori kökenli olduğunu belirterek çağdaş bir bilim görüşü ortaya koymuştur. Bununla birlikte bilimsel bilgilerin tercih edilmesinde veya onların toplumda uzun süre geçerliliğini sürdürmesinde bilim insanlarının popülerliğinin de etkili olacağını belirterek bilim insanlarını farklı bir yerde konumlandıran görüşlere sahip öğretmen adayları da mevcuttur. Ö̆ğretmen adaylarının birçoğu kanıtlanabilirlikle bilimsel yasayı bir bütün olarak algıladıkları ve bilgi türleri arasında hipotezden bilimsel yasaya doğru giden hiyerarşik bir yapının varlığını kabul ettikleri de görülmektedir.

Bilimin test edilebilirlik boyutuna ait BBDÖ verilerine göre (tablo 3) öğretmen adaylarının tamamına yakını bilimsel bilgilerin gözlem ve deneylere dayanması gerekliliğini, deney sonuçlarının tutarlılı̆̆ını ve tekrarlanabilirliğini kabul ettikleri söylenebilir. Benzer sonuçlara kısa hikâyelerden elde edilen bulgulardan da ulaşmak mümkündür. Ancak bu tabloda özellikle on ikinci önerme de katılımcıların beşte birinin kararsız kalmış oldukları da göz önünde bulundurulmalıdır. Kararsız kalan bu katılımcıların bilimsel bilginin toplum incelemesine açı olması ve toplum tarafından kabul edilmesi noktasında kısa hikâyelerde görüşlerini açı bir şekilde ortaya koyabildikleri görülmüştür. 
On ikinci kısa hikâyenin üç sorusu da öğretmen adaylarının bilimin yaratıcılık boyutuna ait görüşleri ortaya çıkarmak için sorulmuştur. Bu sorulara verilen cevaplar birlikte değerlendirilerek analiz edilmiştir. Aşağıda öğretmen adaylarının vermiş oldukları cevaplardan yapılan alıntılar sunulmuştur.

"Soru 3: Bir önceki soruya verdiğiniz cevaptan hareketle sizce bilim daha çok prosedürel (belli bilgi, işlem ve süreç gerektiren) midir? Yoksa yaratıcı (bilim insanlarının hayal gücü, sezgisi, yaratıcılık gibi özelliklerine dayanan) yönü daha mı ă̆ır basar? Parçadan örnek durumlarla cevabınızı kısaca açıklayınız. (Kısa hikâye 12, soru 3)

K-2: Bilim daha çok prosedürel değil yaratıcıdır. Örneğin: Arşimet problemi tespit gözlem veri toplama hipotez deney teori.............şeklinde değil yaratıcilığı ile sonuca ulaşmıştır. Buradan bilimin çoğu zaman yaratıcı yönünün ağır bastı̆̆ı söylenebilir. Diğer soruda da olduğu gibi herkes banyoya girdiğinde suyun yükseldiğini taştı̆̆ını görür ama bakmak ayrıdır. (Kısa hikâye 12, soru 3, A115)

K-3: Bilim adamının yaratıcı yönü ağır basar. Yani bilim adamının yaratıclığı sezgisi ve hayal gücü ön plandadır. Parçada Arşimet suyun yükseldiğini fark etmiş bunu yorumlamıştır. Hayal gü̈ünü kullanmıştır. Çözüm bir anda aklına gelmiştir. Sezgisini kullanarak altının saf olup olmadığını anlamaya çalışmışıır. Tabii ki de bilim belli bir bilgi ya da süreç gerektirir. Ama burada hayal gücü yaratıcılık gibi unsurlar daha fazla ön plana çıkar. (Kısa hikâye 12, soru 3, A116)

K-31: Bence bilim hem prosedürel hem de yaratıcllik gerektirir. Ama ne kadar bilimsel bilgiye sahip olunsa da bu bilgileri farklı bakış açılarıyla bakıp yorumlamadan istene bilimsel bilgiye ulaşılamaz. Farklı bakış açıları da hayal gücüne, sezgiye, yaratıcllı̆̆a dayanır. Yani bence yaratıcllı bilimde daha önemlidir. Örneğin parçada da tacın saf olup olmadığını tacı bozmadan çözümlemeye çalışılıyor ve bu problemi çözmek için başka insanlarda uğ raşıyor.

Fakat onların hiçbirinde Arşimet'in bakış açısı hayal gücü mevcut değill. (Kısa hikâye 12, soru 3, A118)"

Bilimin yaratıcılık boyutuyla ilgili soruların cevaplarından elde edilen bulgular birlikte değerlendirildiğinde öğretmen adaylarının birçoğunun bilimsel bilgilerin oluşturulmasında bilim insanlarının yaratıcılık, hayal gücü, sezgi gibi özelliklerin önemli bir rol oynadığını vurguladıkları görülmüştür. Ayrıca bilimsel çalışmalarda yapılan olgusal gözlemlerin teori kökenli olduğu ve kültürün, sosyal çevrenin bilimsel açıklamaları etkilediği görüşü sıklıkla dile getirildiği görülmüştür. Bilimsel etkinliklerin prosedürel yönü ve yaratıcı yönü arasındaki ilişkileri ortaya koyan sorulara verilen cevaplarda öğretmen adaylarının tam bir görüş birliği içinde olmadıkları görülmüştür.

Bilimin yaratıcılık boyutuna ait BBDÖ verilerine göre (Tablo IV) bilimin yaratıcılık boyutuna ait önermelere kırk birinci önerme dışında genelde katıldıkları söylenebilir. Ayrıca kırk birinci önermeyle ilgili olarak katılımcıların yarısından fazlasının $(\% 67,1)$ bilimsel bilgilerin keşfedildiği icat edilmedikleri inancına sahip oldukları söylenebilir. Bu sonuç diğer önermelerden elde edilen bulgularla birlikte düşünüldüğünde ortada bir sorun olduğu söylenebilir. Katılımcılar diğer önermelerde bilimin yaratıcı doğasına ilişkin önermelere büyük çoğunlukla katılırken son önermeye katılmamışlardır. Oysaki son önermede geçen icat etme kavramı bilimsel bilginin ve bilim insanlarının yaratıcı yönüne vurgu yapan bir ifadedir. Bunun olası bir nedeni katılımcıların icat ve keşif terimlerini tam olarak algılayamamış olmaları olabilir. Bu bulgunun bir yansıması kısa hikâyelere verilen cevaplarda da 
görülmektedir. Bilimin yaratıcllı boyutuna ilişkin sorulan bütün sorulara verilen cevaplarda icat ve keşif kavramlarını çok az kullandıkları ya da yanlış kullandıkları görülmüştür. Bu bulgudan öğretmen adaylarının bu iki kavrama yönelik sahip oldukları tanımların yeterli olmadığı sonucuna ulaşılabilir.

Kısa hikâyelere verilen cevapların içerik analizi sonrasında çalışmaya katılan fen bilgisi öğretmen adaylarında saptanan bazı kavram yanılgıları aşağıda özetlenmiştir.

- Hipotezler teorilere, teoriler de daha fazla kanitlar bulunarak kanunlara dönüşür.

- Bilimsel yasalar doğruluğu kesin ve mutlak bir biçimde kanıtlanmış ve bilimsel bilginin gelebileceği son nokta olarak görülmektedir.

- Bilim insanları bilimsel araştırmalarda ilk önce gözlemlerini yaparlar daha sonra kuramsal yapiların oluştururlar.

- Deneyler bilimsel bilgilerin oluşturulmasında en temel yöntemdir.

- Bilimsel bilgiler keşfedilir, icat edilmez.

\section{Tartışma Sonuç ve Öneriler}

Öğretmen adaylarının büyük bir bölümünün bilimin gelişimiyle ilgili olarak onun birikimsel bir süreç içerisinde basamak basamak ilerlediğini vurguladıkları görülmüştür. Bilimin sürekli yenilenerek, gelişerek, değişebilen bilgiler yığını ve birikimli bir süreç olarak tanımlayan öğretmen adaylarının sayısı bu araştırmada oldukça fazladır. Bu sonuç daha önce farklı zamanlarda fen öğretmenleri ve öğretmen adayları ile yapılan araştırma sonuçları (Yakmacı, 1998; Haidar, 1999; Kahyaoğlu, 2004; Erdoğan, 2004; Doğan Bora, 2005; Aslan, 2009; Sarıtaş, 2013) ile oldukça benzerlik göstermektedir. Bu çalışmalarda da öğretmenlerin veya öğretmen adaylarının büyük bir bölümünün bilimin tanımına yönelik gerçekçi görüşlere sahip olmadıkları görülmüştür. Çok az sayıda öğretmen adayı bilimin bazen kesintilere uğrayacağını ve böylesi durumlarda paradigmanın değişeceğini, bilimde ilerlemenin yine de devam edeceğini belirtmiştir

Bilimin test edilebilirlik boyutuna ilişkin cevaplardan elde edilen bulgular birlikte değerlendirildiğinde öğretmen adaylarının birçoğunun bilimsel bilgilerin tercih edilmesinde ve toplumda geçerlilik kazanmasında olgusal gözlemlere ve deneylere dayandırılması gerektiğine inanmakta oldukları görülmüştür. Benzer sonuçlara Rubba ve Andersen, (1978); Güzel, (2004); Gücüm, (2000)'ün araştırmalarında rastlamak mümkündür.

Bilimin yaratıclık boyutuyla ilgili olarak öğretmen adaylarını birçoğunun bilimsel bilgilerin oluşturulmasında bilim insanlarının yaratıcılık, hayal gücü, sezgi gibi özelliklerinin önemli bir rol oynadığını vurguladıkları görülmüştür. Araştırmaya katılan öğretmen adaylarının büyük bir çoğunluğu bilim insanlarının karakteristik özellikleri hakkında gerçekçi görüşlere sahiptir. Öğretmen adayları büyük oranda başarılı bilim insanlarının çalışmalarında daima çok açık fikirli, mantıklı, önyargısız 
ve nesnel olmalarının yanında hayal gücü, zekâ ve dürüstlük gibi özellikleri de taşıması gerektiğin noktasında birleşmişlerdir.

Öğretmen adaylarının rubrik puanlarına ait sonuçlar genel olarak değerlendirildiğinde bilimin doğası hakkında bu araştırmaya konu olmuş üç boyutta da gerçekçi, çağdaş olarak kabul edilen görüşlere sahip olmadıkları görülmüştür. Gelişimsellik, test edilebilirlik ve yaratıcılık boyutlarının tamamında öğretmen adaylarının büyük bir bölümünün naif ya da orta düzey sayılan görüşleri dile getirdikleri görülmüştür.

Öğretmen adaylarının BBDÖ puanlarına ait sonuçlar genel olarak değerlendirildiğinde bilimin doğası hakkında bu araştırmaya konu olmuş üç boyutta gerçekçi, çağdaş olarak kabul edilen görüşlere sahip oldukları görülmüştür. Ancak birkaç önermede az da olsa bazı öğretmen adaylarının naif ya da geleneksel sayılan görüşleri dile getirdikleri görülmüştür.

Çalışmada kullanılan BBDÖ ne verilen cevaplardan katılımcıların anlayışları bir tahminden öteye gidememiştir. Aikenhead, (1988) likert tipteki bu araçlarda belirsizliğin \% 80'lere vardığını belirtmiştir. Çünkü katılımcıların belli önermelere hangi oranda katılıp hangi oranda katılmadıkları bir belirsizlik taşımaktadır. Bu araştırmada kullanılan KHY, katılımcılara bilimin doğası hakkında ki görüşlerini hikâyelerde sunulan olaylar ve kişiler arasındaki kurgulardan yola çıkarak herhangi bir sinırlamaya veya yönlendirmeye maruz kalmaksızın ortaya koymaya imkân sağlamaktadır. Kısa hikâyeler katılımcılara diğer araçlarda olmayan düşünsel bir ortam sağlayarak onların bilmiyorum ya da anlamadım gibi cevapları seçme olasılığı olan kişilere de görüşlerini açıklama fırsatı sunmaktadır. Ayrıca kısa hikâyelere verilen cevapları değerlendirmek için hazırlanmış olan rubrikler aracılı̆̆ıyla katılımcılara nicel bir değer verilebilmektedir. Böylece bu yöntemle standart ölçeklerden elde edilen sonuçlar gibi sonuçlara ulaşmak mümkün olabilmektedir.

Son söz olarak bilim ve bilimin doğası gibi tanımları üzerinde herhangi bir konsensüs sağlanamamış olan kavramlara ilişkin görüşleri ortaya koymak için açık uçlu ve cevaplayanları yönlendirmeyen ancak içerisinde barındırdığı olay, olgu, kişi ve zaman unsurlarıyla katılımcılara yararlı uyaranlar sağlayan kısa hikayelerin oldukça yararlı oldukları görülmüştür.

$\mathrm{Bu}$ araştırmanın bulguları ve sonuçları göz önünde bulundurularak aşağıdaki öneriler geliştirilmiştir.

- Öğretmen adaylarının bilimin doğası konularında sahip oldukları kavram yanılgılarının kaynağı hakkında detaylı araştırmalar yapılmalıdır.

- Fen bilgisi öğretmen adaylarına müfredatlarında yer alan fizik, kimya ve biyoloji derslerinde veya sınıf içi uygulamalarda bilimsel modellerin, teorilerin, yasaların kullanılmasına imkân sağlanmalıdır. Ve öğretmen adaylarının bilimi gerçekler paketi ya da sade kuru bilgiler olarak görmek yerine bilimsel bilginin tarihi gelişimi içerisinde nasıl elde edildiği, bilimsel 
devrimlerin ne anlama geldiği, bilimsel bilgilerin neden sonuç ilişkileriyle gösterilmesi gibi daha çağdaş olan özellikleri kazanmaları için fizik, kimya, biyoloji gibi derslerde imkânlar sağlanmalıdır.

- $\mathrm{Bu}$ araştırmada fen bilgisi öğretmen adaylarının bilimin doğası hakkındaki görüşlerini değerlendirmek üzere yazılı olarak sunulmuş 8 kısa hikâye kullanılmıştır. Daha sonra bu amaçla yapılacak araştırmalarda farklı sayıda ve farklı formatta kısa hikâyeleri de içeren değerlendirme yöntemleri kullanilmalıdır.

\section{Kaynaklar}

Abell, S. K., and Smith, D. C. (1994). What is science? Preservice elementary teachers' conceptions of the nature of science. International Journal of Science Education, 16(4), 475-487.

Aikenhead, G. S. (1988). An Analysis of Four Ways of a Assessing Student Beliefs About STS Topics. Journal of Research in Science Teaching. 25(8). 607- 629.

Aikenhead, G. S., and Ryan, A. G. (1992). The development of a new instrument: "Views on science - technology - society"(VOSTS). Science Education, 76(5), 477- 491.

American Association for the Advancement Of Science (AAAS). (1993). Benchmarks for science literacy: A Project 2061 report.New York: Oxford University Press.

Aslan, O. (2009). Fen Ve Teknoloji Öğretmenlerinin Bilimin Doğası Hakkındaki Görüşleri Ve Bu Görüşlerin Sınıf Uygulamalarına Yansımaları.Yayınlanmamış Doktora Tezi, Gazi Üniversitesi Eğitim Bilimleri Enstitüsü, Ankara.

Atasoy, B.(2002). Fen Öğrenimi ve Öğretimi.Ankara: Gündüz Yayıncılık.

Bilgiç, M. (1985). The effectiveness of inquiry oriented laboratory on students' understanding of the nature of scientific knowledge at university level. Unpublished master's thesis. Middle East Technical University, Ankara.

Doğan Bora, N. (2005). Türkiye Genelinde Ortaöğretim Fen Branşı Öğretmen Ve Öğrencilerinin Bilimin Doğası Üzerine Görüşlerinin Araştırılması. Yayınlanmamış Doktora Tezi, Gazi Üniversitesi Eğitim Bilimleri Enstitüsü, Ankara.

Driver, R., Leach, J., Millar, R., \& Scott, P. (1996). Young People's Images of Science.Buckingham, UK: Open University Press.

Erdoğan, R. (2004). Investigation Of The Preservice Science Teachers' Views On Nature Of Science. Unpublished Master's Thesis. Middle East Technical University The Graduate School of Natural and Applied Sciences, Ankara.

Gücüm, B. (2000, 6-8 Eylül). Fen Bilgisi Öğretmenliği Öğrencilerinin Bilimsel Bilginin Yapısını Anlama Düzeyleri Üzerine Bir Araştırma. IV. Fen Bilimleri Eğitimi Kongresinde sunuldu, Hacettepe Üniversitesi Eğitim Fakültesi, Ankara. 
Güzel, H. (2004, 9-11 Eylül). Fizik Bölümü Öğrencilerinin Bilimsel Bilginin Yapısını Anlama Düzeyleri. VI. Ulusal Fen Bilimleri Ve Matematik Eğitimi Kongresinde sunuldu, Marmara Üniversitesi Atatürk Eğitim Fakültesi, İstanbul.

Haidar, A. H. (1999). Emirates pre-service and in-science techers' views about the nature of science. International Journal of Science Education, 21(8), 807-822.

Hogan, K. (2000). Exploring a process view of students' knowledge about the nature of science. Science Education, 84(1), 51-70.

Kahyaoğlu, E. (2004). Turkish Preservice Science Teachers' Views on STS: Characteristics of Scientists' Work. Unpublished master's thesis, Middle East Technical University, Ankara.

Lederman, N. G., Abd-El-Khalick, F., Bell, R. L., and Schwartz, R. S. (2002). Views of nature of science questionnaire: Toward a valid and meaningful assessments of learners' conceptions of nature of science. Journal of Research in Science Teaching, 39(6), 497521.

Lederman, N. G., and O'Malley, M. (1990). Students' perceptions of tentativeness in science: Development, use, and sources of change. Science Education, 74(2), 225-239.

Lederman, N. G., Wade, P., and Bell, R. L. (2000). Assessing Understanding of the Nature of Science: A Historical Perspective. In W. F. McComas (Ed.), The Nature of Science in Science Education ( pp 331- 350). Dordrecht, Boston, London: Kluwer Academic Publishers.

Milli Eğitim Bakanlı̆̆1. (2005). İlkögretim 6. ve 7. ve 8. Sinıf Fen ve Teknoloji Dersi Ögretim Programları. Ankara: Milli Eğitim Bakanlığı Talim ve Terbiye Kurulu Başkanlığı.

Moss, D. M., Abrams, E. D., and Robb, J. (2001). Examining student conceptions of the nature of science. International Journal of Science Education, 23(8), 771-790.

Murcia, K., and Schibeci, R. (1999). Primary Student Teachers' Conceptions Of The Nature Of Science. International Journal of Science Education, 21(11), 1123-1140.

National Research Council. (1996). National Science Education Standards. Washington, D.C: National Academy Press.

National Science Teachers Association. (1982). Science- Technology- Society: Science education for the 1980s. Washington, DC: Author.

Polat, M. (2011). Bilimin Doğası Hakkındaki Görüşlerin Kısa Hikâyeler Yöntemiyle Değerlendirilmesi: Fen Bilgisi Öğretmen Adayları Örneği. Yayınlanmamış Doktora Tezi, Gazi Üniversitesi Eğitim Bilimleri Enstitüsü, Ankara.

Rubba, P. A., Andersen, H. O. (1978). Development of an instrument to assess secondary school students` understanding of the nature of scientific knowledge. Science Education, 62(4), 449-458.

Sarıtaş, D. (2013). Periyodik sistemin öğretim sürecinde oluşan rasyonel bilginin; üretimi, epistemolojisi ve metodolojisi. Yayımlanmamış doktora tezi. Gazi Üniversitesi Eğitim Bilimleri Enstitüsü, Ankara.

Solomon, J., (1991).Exploring The Nature Of Science. Glasgoew, England: Blackie. 
Taşar, M. F. (2006). Probing preservice teachers' understandings of scientific konowledge by using a vignette in conjuction with a paper and pencil test. Eurasia Journal of Mathematics, Science and Technology Education, 2(1), 53- 70.

Tsai, C-C. (2002). Nested epistemologies: science teachers' beliefs of teaching, learning and science. International Journal of Science Education, 24(8), 771-783.

Yakmac1, B. (1998). Science (Biology, Chemistry and Physics) Teachers' Views on the Nature of Science as a Dimension of Scientific Literacy. Unpublished Master's Thesis, Boğaziçi University, Institute of Social Science, İstanbul.

Yıldırım, A. ve Şimşek, H. (2006). Sosyal Bilimlerde Nitel Araştırma Yöntemleri. (5. Baskı). Ankara: Seçkin Yayıncılık. 